\title{
Child Involvement in Family Financial Management and Subjective Well-Being of Children from the Intact and Non-Intact Families
}

\author{
Leti Nurhayati $^{1 *}$, Istiqlaliyah Muflikhati ${ }^{2}$ \\ ${ }^{1,2}$ Department of Family and Consumer Sciences, Faculty of Human Ecology, IPB University, \\ Bogor 16680, West Java, Indonesia \\ *) Corresponding author: letinurhayati15@gmail.com
}

\begin{abstract}
The purpose of this research is to analyze the influence of child involvement in family financial management and material well-being on children's subjective well-being among children from intact families and non-intact families. Fifty students from intact families and fifty students from the nonintact family have participated in this research. The students were selected using stratified random sampling techniques from junior high schools in Bogor Regency. Data were collected using a selfadministered questionnaire and were followed with in-depth interviews with some students. The result of this research showed that child involvement, material well-being, and subjective well-being were categorized as medium. The result of the independent sample T-test showed that there were no significant differences between students from intact families and students from non-intact families in terms of their involvement in family financial management, material well-being, and subjective well-being. The result of the multiple linear regression test showed that child involvement in family financial management significantly positively affected their subjective well-being. Thus, the higher the children involved in family financial management, the better their subjective well-being.
\end{abstract}

Keywords: child involvement, intact family, material well-being, non-intact family, subjective wellbeing

\begin{abstract}
Abstrak
Tujuan penelitian ini adalah untuk menganalisis pengaruh keterlibatan anak dalam mengelola keuangan keluarga dan kesejahteraan materi terhadap kesejahteraan subjektif anak pada keluarga utuh dan keluarga tidak utuh. Contoh yang diambil pada penelitian ini adalah anak usia remaja. Metode pengambilan contoh yang dilakukan pada penelitian ini adalah metode stratified random sampling berdasarkan struktur keluarga utuh dan keluarga tidak utuh. Contoh yang diambil sebanyak 100 siswa SMP di Kabupaten Bogor, terdiri dari 50 siswa dari keluarga utuh dan 50 siswa dari keluarga tidak utuh. Data dikumpulkan melalui pengisian kuesioner oleh siswa dan beberapa wawancara secara mendalam. Hasil penelitian menunjukkan keterlibatan anak dalam mengelola keuangan keluarga, kesejahteraan materi, dan kesejahteraan subjektif anak tergolong sedang. Hasil uji sampling-independent T-test menunjukkan tidak ada perbedaan yang signifikan antara keterlibatan anak dalam mengelola keuangan keluarga, kesejahteraan materi, dan kesejahteraan subjektif anak pada keluarga utuh dan keluarga tidak utuh. Hasil uji regresi linier berganda menunjukkan bahwa keterlibatan anak dalam mengelola keuangan keluarga berpengaruh positif signifikan terhadap kesejahteraan subjektif anak. Hal ini berarti bahwa semakin tinggi keterlibatan anak dalam mengelola keuangan keluarga akan meningkatkan kesejahteraan subjektif anak.
\end{abstract}

Kata kunci: kesejahteraan materi, kesejahteraan subjektif, keterlibatan anak, struktur keluarga 


\section{Introduction}

Happiness is often referred to as subjective well-being (Schimmel, 2009). Well-being refers to adequate basic life needs, such as clothing, food, shelter, health, education, employment, and security (Ministry of Women Empowerment and Child Protection, 2010). As the smallest entity that forms a society, the well-being of the family and its members, including the well-being of children as the next generation is essential. According to Diener and Laresen (1984) cited in Main et al. (2019), the subjective well-being of children is an assessment of their quality of life. Child well-being is essential to understand because wellbeing will affect children's lives in the future (Ben-Arieh, 2008).

The family has a crucial role in realizing well-being for each family member (Puspitawati, 2012). Family conditions, in this case, the family structure, is proven to affect the well-being of children (Steele, Sigle-Rushton, \& Kravdal, 2009). The structure of an incomplete family such as single-parent family or family without parents (hereinafter referred to as non-intact family) continues to increase along with the increased divorce rate each year. In 2014 the divorce rate in Indonesia totalled 344,237 cases, rising to 365,633 cases in 2016 (Statistics Indonesia, 2017). By province, West Java had the second-highest number of divorce cases with 79,047 cases in 2017. Furthermore, Bogor Regency is a district area in West Java with 2,970 cases of divorce in 2016 and increased to 3,310 cases in 2017 (Judicial Agency Religion, 2018). Apart from divorce, non-intact families can be formed by the death of a spouse, pregnancy before marriage, and adoption (Soemanto \& Haryono, 2018).

The prior study found that children who lived with a single parent (mother) had lower material resources and parental support than those with complete parents (Laftman, 2009). Children's satisfaction about ownership of goods and services (material resources) is also known as material well-being. Material well-being is defined as the source of material that can be accessed by children (Diener \& Larsen, 1984 cited in Main et al., 2019) including concepts such as money satisfaction, financial stress, financial security, and material wellbeing (Sirgy, 2018). Travers and Rischardson (1993) in Sirgy (2018) stated that the household's net income, the purchasing power to meet the needs for living standards, homeownership, savings, and free time paid affect material well-being. When the resources owned can meet current and future needs, individuals perceive subjective material wellbeing (Hansen, Slagsvold, \& Moum, 2008).

In managing family resources, including material resources, the family carries out activities to organize and make decisions. Each family member can make decision making in the family. However, there will be more members who have more control in deciding family decisions. Few parents do not involve their children in determining family decisions. As stated by Neil (1962) in Sitepu (2014), many parents did not allow children to participate in decisions related to their needs. However, Ben-Arieh's (2008) found that it was essential to involve children in decision making regarding children's lives. Involving children in making decisions about financial management is one of the lessons for children. Children's experience in managing finances is needed and will affect children's lives in the future (Yulianti \& Silvy, 2013).

According to Rees and Main (2015), measurement on child well-being are still lagging compared to measurements on adult well-being. More research conducted leads to adult opinions about children's needs without involving children directly (Main, 2019). Given the importance of involving children in the family financial management, research on this topic needs to be improved. 
Based on the description above, this study aims to 1) identify child characteristics, family characteristics, child involvement in managing family finances, material well-being, and subjective well-being of children in intact and non-intact families; 2) analyze differences in child involvement in family financial management, material well-being, and subjective well-being of children in intact and non-intact families; 3) analyze the influence of child characteristics, family characteristics, child involvement in family financial management, and material well-being on child subjective well-being in intact and non-intact families.

\section{Methods}

\section{Research Design}

This study used a cross-sectional study design. The research approach was a survey technique.

\section{Participants}

The unit of analysis of this study was families with junior high school-aged children. The approach for data collection was carried out through schools and children as participants in the study. The selection of research locations was based on the consideration that the State Junior High School (SMPN) students had quite a variety of characteristics and a large number of students. The study was conducted in March 2019. Participants in this study were 100 students in SMPN 1 Dramaga with the criteria of living with intact and non-intact family. Sampling techniques used the stratified random sampling method based on intact and non-intact family groups. Data on intact and non-intact families were obtained by conducting a screening census to all 7 th and 8th grades with a total of 835 people. From the results of the screening, 59 data were obtained from students from non-intact families and the rest from intact families. A sample of 50 students was chosen randomly from each category of intact and not intact families.

\section{Measures}

The involvement of children in family financial management in this study is the child's perception of his/her involvement in decision making regarding his needs. The measurement tool for child involvement in family financial management was developed by researchers referring to the instrument of Main (2019) with a Cronbach's alpha value of 0.533. The responses for child involvement in family financial management were rated on a 4-point scale ("never", "sometimes", "often", and "always"). Material well-being describes child ownership and access to goods and services in the family. Material well-being was measured using an instrument modified from Main (2019) consisting of nine statements. The scale used was the Guttman scale with the answer choices "no" or "yes".

Subjective well-being is the satisfaction that the child feels about his quality of life. Children's subjective well-being was measured using the Personal Well-Being Index (School-Children) adopted from Cummins and Lau (2005) by changing the measurement scale of 10 points to 5 points ("very dissatisfied", "not satisfied", "normal", "satisfied", "very satisfied"). This instrument consists of seven dimensions with one statement each: living standards, health, achievement, personal relationships, present security, future security, and social issues. The Cronbach's alpha value of this instrument was 0.653 . Each question provided five answers; "very dissatisfied", "dissatisfied", "normal", "satisfied", and "very satisfied". 


\section{Data Collection Technique}

Data were collected in the form of primary data. Primary data were obtained through filling out questionnaires by the children consisting of child characteristics, family characteristics, child involvement in family financial management, material well-being, and subjective well-being of children. In addition to filling out the questionnaire, in-depth interviews were also conducted with several samples.

\section{Analysis}

Data collected through questionnaires were then processed and analyzed using Microsoft Excel and SPSS 21 for windows. Data processing included editing, coding, entry, scoring, and analysis. Child involvement in family financial management was measured using eight statements with an answer score of 1 to 4 so that the lowest score of 8 was obtained and the highest score was 32. Material well-being was measured using nine statements with an answer score of 0 and 1 so that the lowest and highest scores were obtained were 0 and 9, respectively. Subjective well-being of children was measured using seven statements with a score of 1-5, so that the lowest and highest scores obtained were 7 and 35, respectively. Each score obtained from the measurement of the studied variable were transformed into an index score. The following formula calculated the index score of each variable:

$$
=\underset{=}{\text { Index }} \frac{\text { obtained score-minimum score }}{\text { maximum score-minimum score }} \times 100
$$

where:

Index $\quad=$ score $0-100$

Obtained score $\quad=$ score obtained by the participant

Minimum score $\quad=$ the lowest score obtained by the participant

Maximum score $\quad=$ the highest score obtained by the participant

The index was categorized into three categories (Khomsan, 2000), namely low $(<60)$, moderate (60-80), and high (>80). Data were analyzed using descriptive analysis and inferential analysis. Descriptive analysis included frequency distribution, standard deviations, minimum, maximum, and mean values. The inferential analysis included the independent-sample T-test and the multiple linear regression test. The independent-sample T-test analysis was used to examine the difference of child involvement in family financial management, material well-being, and subjective well-being of children in intact and nonintact families. Multiple linear regression test was used to analyze the effect of child characteristics, child involvement in family financial management, and material well-being on children's subjective well-being. The linear equation used for the regression test is as follow:

$$
Y=\alpha+\beta_{1} X_{1}+\beta_{2} X_{2}+\beta_{3} X_{3}+\beta_{4} X_{4}+\beta_{5} X_{5}+\beta_{6} X_{6}+\beta_{7} X_{7}+\varepsilon
$$

where:

Y : child subjective well-being (index)

$\alpha$ : constant

$\beta_{1-7}:$ regression coeffiient 


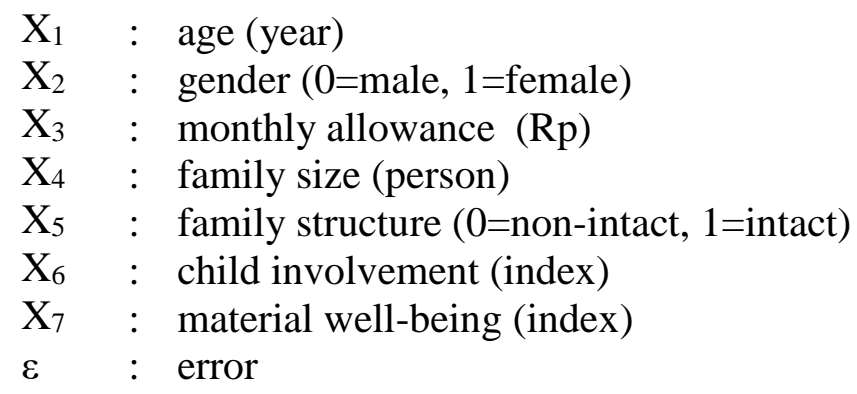

\section{Findings}

\section{Child and Family Characteristics}

Participants in this study were 7th and 8th-grade students of SMPN 1 Dramaga. Table 1 shows that there are more female participants compared to male participants from both intact and intact families. Adolescence categories based on Monks, Knoers, and Haditono (2001) are pre-adolescence (10-12 years), early adolescents (12-15 years), middle adolescents (15-18 years), and advanced adolescents (18-21 years). Overall, participants in this study were categorized as early adolescents with the most substantial proportion of children in intact families aged 13 years and non-intact families aged 14 years. The birth order of most participants was the middle child in intact families and youngest child in nonintact families. The family size of the intact family was smaller than the intact family. It is because the majority of children from non-intact families only lived with one parent and siblings, whereas children from the intact family lived with both parents and there were cases of residing with uncles, aunts, grandfathers, and grandmothers.

The average monthly allowance was Rp400,000. The monthly allowance was used for various purposes such as snacks, transportation, and partly for saving. The amount of allowance for children from intact and non-intact families with the largest proportion was in the range of Rp300,000 to Rp600,000. The allowance for children from non-intact families amounted to at least Rp7,000 per day.

Participants in this study were adolescents who came from intact and non-intact families with a total of 100 children. As many as 50\% of participants from intact families lived with both parents, $38 \%$ lived with single mothers, $9 \%$ lived with single fathers, and the rest lived with grandparents without biological parents.

The non-intact family was formed through divorced parents or parent death. As many as 3 participants who lived with grandparents was due to one or both parent died. Every child has a different length of time since parents abandoned it. Six out of 50 children have been abandoned for more than 12 years since they were babies. The average child is left at the age of 7 years at elementary school age.

Most of the mothers in intact families did not work while fathers became the primary breadwinners of the family. Fathers worked as an entrepreneur such as owning a food stall, traders and holding his own business. While the majority of mothers from the intact family were not involved in the public sector, as many as $22 \%$ of mothers worked to supplement the family income. In contrast, single parents had a workload so that either single fathers or single mothers from the non-intact family worked to support the family. Mother from the non-intact family in this study worked as a laborer or had her own business such as trading, owning laundry, and being a household assistant. 
Table 1. Distribution of participants by sex, age, birth order, and allowance

\begin{tabular}{|c|c|c|c|c|c|c|}
\hline \multirow{2}{*}{ Characteristic } & \multicolumn{2}{|c|}{ Intact family } & \multicolumn{2}{|c|}{ Non-intact family } & \multicolumn{2}{|r|}{ Total } \\
\hline & $\mathrm{n}$ & $\%$ & $\mathrm{n}$ & $\%$ & $\mathrm{n}$ & $\%$ \\
\hline \multicolumn{7}{|l|}{ Gender } \\
\hline Male & 19 & 38.0 & 15 & 30.0 & 34 & 34.0 \\
\hline Female & 31 & 62.0 & 35 & 70.0 & 66 & 66.0 \\
\hline Total & 50 & 100.0 & 50 & 100.0 & 100 & 100.0 \\
\hline \multicolumn{7}{|l|}{ Age } \\
\hline 12 years & 16 & 32.0 & 10 & 20.0 & 26 & 26.0 \\
\hline 13 years & 25 & 50.0 & 18 & 36.0 & 43 & 43.0 \\
\hline 14 years & 9 & 18.0 & 20 & 40.0 & 29 & 29.0 \\
\hline 15 years & 0 & 0.0 & 2 & 4.0 & 2 & 2.0 \\
\hline Total & 50 & 100.0 & 50 & 100.0 & 100 & 100.0 \\
\hline Min-Max & \multicolumn{2}{|c|}{$12-14$} & \multicolumn{2}{|c|}{$12-15$} & \multicolumn{2}{|r|}{$12-15$} \\
\hline Mean \pm SD & \multicolumn{2}{|c|}{$12.86 \pm 0.7$} & \multicolumn{2}{|c|}{$13.28 \pm 0.83$} & \multicolumn{2}{|r|}{$13.07 \pm 0.79$} \\
\hline \multicolumn{7}{|l|}{ Birth order } \\
\hline Only child & 3 & 6.0 & 9 & 18.0 & 12 & 12.0 \\
\hline First child & 7 & 14.0 & 12 & 24.0 & 19 & 19.0 \\
\hline Middle child & 25 & 50.0 & 9 & 18.0 & 34 & 34.0 \\
\hline Youngest child & 15 & 30.0 & 20 & 40.0 & 35 & 35.0 \\
\hline Total & 50 & 100.0 & 50 & 100.0 & 100 & 100.0 \\
\hline \multicolumn{7}{|c|}{ Monthly allowance (thousand Rp) } \\
\hline $0-300$ & 6 & 12.0 & 11 & 22.0 & 17 & 17.0 \\
\hline $301-600$ & 37 & 74.0 & 31 & 62.0 & 68 & 68.0 \\
\hline $601-900$ & 7 & 14.0 & 6 & 12.0 & 13 & 13.0 \\
\hline$>900$ & 0 & 0.0 & 2 & 4.0 & 2 & 2.0 \\
\hline Total & 50 & 100.0 & 50 & 100.0 & 100 & 100.0 \\
\hline Min-Max & \multirow{2}{*}{\multicolumn{2}{|c|}{$\begin{array}{c}260-900 \\
495.48 \pm 148.24 \\
5\end{array}$}} & \multicolumn{2}{|c|}{$202-1.102$} & \multicolumn{2}{|r|}{$202-1.102$} \\
\hline Mean \pm SD & & & & 175.210 & & $476.62 \pm 162.57$ \\
\hline
\end{tabular}

\section{Child Involvement in Family Financial Management}

Table 2 shows that the overall involvement of children in family financial management is low both in intact families and non-intact families. This finding indicates that only a few parents involved their children in family financial decisions. Parents rarely asked children about decision making in the household. The results of the independent sample T-test showed that there was no significant difference in child involvement in family financial management between children from intact and non-intact families.

Table 2. Distribution of participants by category of child involvement in family financial management

\begin{tabular}{|c|c|c|c|c|c|c|}
\hline \multirow{2}{*}{ Category } & \multicolumn{2}{|c|}{ Intact family } & \multicolumn{2}{|c|}{ Non-intact family } & \multicolumn{2}{|c|}{ Total } \\
\hline & $\mathrm{n}$ & $\%$ & $\mathrm{n}$ & $\%$ & $\mathrm{n}$ & $\%$ \\
\hline Low $(<60)$ & 41 & 82.0 & 42 & 84.0 & 83 & 83.0 \\
\hline Moderate $(60-80)$ & 9 & 18.0 & 6 & 12.0 & 15 & 15.0 \\
\hline High $(>80)$ & 0 & 0.0 & 2 & 4.0 & 2 & 2.0 \\
\hline Total & 50 & 100.0 & 50 & 100.0 & 100 & 100.0 \\
\hline Min-Max (index) & \multicolumn{2}{|c|}{$20.8-75.5$} & \multicolumn{2}{|c|}{$20.8-87.5$} & \multicolumn{2}{|c|}{$20.8-87.5$} \\
\hline $\begin{array}{l}\text { Mean } \pm \text { SD (index) } \\
p \text {-value }\end{array}$ & \multicolumn{2}{|c|}{$48.17 \pm 12.852$} & \multicolumn{2}{|c|}{$\begin{array}{c}47.25 \pm \\
15.670\end{array}$} & \multicolumn{2}{|c|}{$47.70 \pm 14.265$} \\
\hline
\end{tabular}




\section{Material Well-being}

Material well-being is measured by the child's ownership and access to goods and services. Table 3 shows that the highest proportion of material well-being of children was categorized as moderate for both family structures with an overall average of 65.57. It means that most children had sufficient access to goods and services. The average child could access 6 to 7 goods and services. Independent sample T-test results showed that there was no significant difference in the material well-being of children from both intact and non-intact families.

Table 3. Distribution of participants by material well-being category

\begin{tabular}{lcccccc}
\hline \multirow{2}{*}{ Category } & \multicolumn{2}{c}{ Intact family } & \multicolumn{2}{c}{ Non-intact family } & \multicolumn{2}{c}{ Total } \\
\cline { 2 - 7 } & $\mathrm{n}$ & $\%$ & $\mathrm{n}$ & $\%$ & $\mathrm{n}$ & $\%$ \\
\hline Low $(<60)$ & 17 & 34.0 & 22 & 44.0 & 39 & 39.0 \\
Moderate (60-80) & 27 & 54.0 & 24 & 48.0 & 51 & 51.0 \\
High (>80) & 6 & 12.0 & 4 & 8.0 & 10 & 10.0 \\
\hline Total & 50 & 100.0 & 50 & 100.0 & 100 & 100.0 \\
Min-Max (index) & \multicolumn{3}{c}{$33.3-100$} & & $33.3-100$ & $33.3-100$ \\
Mean \pm SD (index) & $67.57 \pm 15.209$ & $63.57 \pm 16.048$ & $65.57 \pm 15.684$ \\
-value & \multicolumn{2}{c}{0.204} & & \\
\hline
\end{tabular}

\section{Child Subjective Well-being}

Subjective well-being is what children feel about their quality of life. Table 4 shows that the subjective well-being of children as a whole is moderate, both in intact and nonintact families. The average satisfaction of children from non-intact families was higher than intact families, but the results of the independent T-test showed that there was no significant difference between the subjective well-being of children in intact and non-intact families. The average score of child satisfaction from intact families was 67.71 and 72.79 for non-intact families. The lowest score of subjective well-being in intact families was 46.4 while in non-intact families was 35.5 .

Table 4. Distribution of participants by subjective well-being categories

\begin{tabular}{|c|c|c|c|c|c|c|}
\hline \multirow[b]{2}{*}{ Category } & \multicolumn{2}{|c|}{ Intact family } & \multicolumn{2}{|c|}{ Non-intact family } & \multicolumn{2}{|c|}{ Total } \\
\hline & $\mathrm{n}$ & $\%$ & $\mathrm{n}$ & $\%$ & $\mathrm{n}$ & $\%$ \\
\hline Low $(<60)$ & 4 & 8.0 & 6 & 12.0 & 10 & 10.0 \\
\hline Moderate (60-80) & 36 & 72.0 & 33 & 66.0 & 69 & 69.0 \\
\hline High $(>80)$ & 10 & 20.0 & 11 & 22.0 & 21 & 21.0 \\
\hline Total & 50 & 100.0 & 50 & $\begin{array}{r}100 . \\
0\end{array}$ & 100 & 100.0 \\
\hline Min-Max (index) & 46.4 & & 35. & & & 6.4 \\
\hline $\begin{array}{l}\text { Mean } \pm \text { SD (index) } \\
\text { p-value }\end{array}$ & 69.71 & & 72.79 & & 71.2 & .387 \\
\hline
\end{tabular}

\section{Effects of Child and Family Characteristics, Child Involvement in Family Financial Management, and Material Well-being on Child Subjective Well-being}

The results of multiple linear regression tests indicate that the involvement of children in family financial management had a positive effect $($ beta $=0.199)$ on the subjective well-being of children (Table 5). It shows that every increase of one unit of child involvement in family financial management will increase child subjective well-being by 0.159 times. The Adjusted R-square value was 0.042. It shows that the variables influenced 
only $4.2 \%$ of children's subjective well-being in this study, and the remaining proportion was influenced by other influential factors that were not examined in the study.

Table 5. Effects of child characteristics, child involvement in family financial management, and material well-being on children's subjective well-being

\begin{tabular}{|c|c|c|c|}
\hline Variable & $\begin{array}{l}\text { Unstandardized } \\
\text { Beta }\end{array}$ & $\begin{array}{c}\text { Standardized } \\
\text { Beta }\end{array}$ & $p$-value \\
\hline (Constant) & 67.256 & & $0.002 * *$ \\
\hline Family structure $(0=$ non-intact; $1=$ intact $)$ & -1.440 & -0.064 & 0.583 \\
\hline Age (year) & 0.526 & 0.037 & 0.731 \\
\hline Gender $(0=$ male; $1=$ female $)$ & -3.002 & -0.126 & 0.221 \\
\hline Monthly allowance (Rp) & -0.006 & -0.085 & 0.427 \\
\hline Family size (person) & -1.659 & -0.214 & 0.057 \\
\hline Child involvement (index) & 0.159 & 0.199 & $0.046 * *$ \\
\hline Material well-being (index) & 0.036 & 0.050 & 0.624 \\
\hline $\mathrm{F}$ & & 1.622 & \\
\hline $\mathrm{R}$ & & 0.110 & \\
\hline Adjusted R-Square & & 0.042 & \\
\hline
\end{tabular}

Note. (**) significant at $p<0.05$

\section{Discussion}

This study measured the influential factors on the subjective well-being of children in intact and intact families. Children in intact families in this study refer to children who live with complete biological parents (father and mother), while children in non-intact families are those who live with single parents (only father or only mother) or grandparents without biological parents. Factors that were predicted to affect the subjective well-being of children in this study included family structure (intact or non-intact), age of the child, gender, monthly allowance, family size, child involvement in family financial management, and material well-being of the child.

The majority of children in intact families aged 13 years old $(50 \%)$, were middle children (50\%) and had a monthly allowance of Rp300,000-Rp600,000. The size of the intact family was categorized moderate with 5-7 members $(60 \%)$. On the other hand, the majority of children in intact families aged 14 years old $(40 \%)$, were youngest children $(40 \%)$ and received a monthly allowance in the same range as children in the intact family of Rp300,000-Rp600,000. The size of the intact family was categorized small with less than four members $(74 \%)$.

In terms of children's involvement in family financial management, the majority of children in intact families showed a moderate level of involvement (72\%). Similar results were shown at the moderate level of involvement of children from non-intact families in family financial management (62\%). Children from intact families showed a higher average score of involvement than children from intact families. However, the statistical test did not reveal any significant differences between these groups of children.

The material well-being of children from two different family structures showed a similar level of well-being, which was classified as moderate. Children from intact families showed higher average material well-being scores than children from non-intact families. However, there were no significant differences between the two groups of respondents. Based on in-depth interviews, children's ownership of goods such as cellphones, televisions, clothes, and allowance was almost fulfilled for all children. No more than $15 \%$ of participants had access to car ownership, considering that in Indonesia, cars are luxury 
items that are generally owned by families with an upper-middle-class economy. Most children never go out with the family. They consider that family trip requires a high cost so that they never spend time to travel with family. Besides, the home of relatives such as an uncle, aunt, grandfather, and grandmother close to the house of children, so they rarely travel even to go on vacation to grandma's house. Some children did not get to buy clothes at least once a year with a higher proportion from the non-intact family (28\%) compared to intact families (14\%).

The subjective well-being of children in intact families (72\%) and non-intact families $(66 \%)$ were in the medium category. The subjective well-being scores of children in intact families were lower than children in incomplete families, but there were no significant differences between the two. This finding is different from Amato and Keith (1991), who stated that children from intact families tended to have better satisfaction than children from non-intact families. Also, a prior study found that children from non-intact families tended to have poorer psychological well-being (Shek, 2007). The inconsistent finding may be due to the prior study was focused on non-intact families due to family disruption (i.e., parental divorce), thus resulting in lower levels of child well-being. However, this study also included non-intact families due to parent deaths which arguably may not affect children's well-being as bad as parental divorce.

Overall, the lowest score of child well-being was on the measurement of satisfaction about social life about their relationship with friends. Based on the results of in-depth interviews, children often feel unrecognized in their group of friends. Children are uncomfortable when someone is hostile and picky when making friends. Sometimes children feel isolated from other friends. Furthermore, as many as $24 \%$ of children from non-intact families are not satisfied with the achievements that have been obtained, while in intact families there is only $12 \%$. Based on the results of in-depth interviews, children are not entirely satisfied with the academic achievements that have been obtained and feel their struggle to learn is not enough to produce the desired results.

The results showed that children's involvement in family financial management had a significant positive effect on children's subjective well-being. It means that the higher the involvement of children in family financial management will increase their subjective wellbeing. These results are consistent with Main's research (2019) that if the child's opinion is considered in a household decision, the child will feel valued his presence and subjective well-being will increase. When children are involved in decisions about their needs, children will be able to learn to make decisions for their lives later on. Parents tend to make unilateral decisions, including family financial decisions related to children. It can be understood because parents have control over every decision to be taken in the family (Rini, 2014). Moreover, participants in this study are early adolescents who may be considered too young to decide for themselves.

Participants in this study were not sufficiently involved in determining their own choices to meet their needs. Like when determining the child's allowance, as much as $32 \%$ of children have never been involved at all. Children are rarely involved, and more often, parents immediately give without asking the child's opinion first. As many as $44 \%$ of children from intact families are seldom involved in determining the family's financial budget. However, some parents sometimes disclose their financial expenses, such as for meal, saving, and pay instalments. As many as half of the participants from the non-intact family are rarely involved in discussions about family financial problems. In non-intact families, financial issues are often faced by the family. Based on the results of in-depth interviews with some children, especially boys, they are reluctant to ask parents about 
financial problems that occur. They also have never been asked for their opinions on the purchase of goods to meet their needs. Also, especially for the youngest children, they are rarely involved in the problem of distributing family finances because parents are more involved with their siblings for their opinion on this matter.

The results of in-depth interviews also show that one of the reasons children are never involved in family financial management is because parents rarely interact with children. Parents who are busy and lack of interaction with children are less likely to ask about what the child wants, so that child opinions are rarely considered. Lack of communication between parents and children is one factor that causes children to be seldom involved in family decision making (Rini, 2014). Well-being or happiness is not only measured through material and non-material but also needs to see the involvement of children in the process of obtaining such well-being or happiness (Main, 2019).

The results of this study indicate that material well-being had no significant effect on children's subjective well-being. This finding is not in accordance with Main's study (2017), which found material well-being had a significant positive impact on children's subjective well-being. Although it did not have a significant effect, material well-being had a positive coefficient on children's subjective well-being. As stated by Sirgy (2018) that the more children accessed goods and services, the higher the level of satisfaction a child had. The results showed that almost all children were able to access four of the seven items of ownership of goods and services. It means that intact or non-intact families are equally able to access goods such as cellphones, televisions, and clothes. Besides, some allowance is used by children to buy things that children need.

The limitation of this study is that it does not take into account the length of time children live in a non-intact family. The children in this study had been left for too long by parents so that there were no differences in subjective well-being between children from intact families and children from incomplete families. This study did not involve parents in the involvement of children in family financial management. The use of the Personal WellBeing Index instrument to measure subjective well-being does not use the original scale by using ten measurement scales.

\section{Conclusion}

\section{Conclusion and Recommendation}

The results showed that participants dominated by girls from both intact and intact families. The average child was 12 to 13 years old. Most participants were middle children in intact families and youngest children from non-intact families. The largest percentage of the allowance was in the range of Rp300,001 to Rp600,000 for both children from intact and intact families. Overall, the involvement of children in family financial management, material well-being, and subjective well-being was categorized moderate for children both from intact and intact families. The involvement of children in family financial management had a significant positive effect on children's subjective well-being.

\section{Recommendation}

The results showed that the involvement of children in family financial management was classified as moderate. To increase the involvement of children, parents or other caregivers should communicate with children more often and train children to make choices, ask the child's opinion about family decisions, especially regarding the child's personal needs. Also, children still feel unsatisfied with social life, especially when there are problems 
with friends. In this case, parents or other caregivers are expected to accompany and give the child emotional support or help the child to solve the problem. Future studies are expected to involve participants who have just been left behind by parents for no more than two years to be able to see the difference between intact and non-intact families. Also, data on children's involvement in family financial management need to be collected from the perspective of parents. Future studies can examine other factors that may affect children's subjective well-being, such as peer interaction, social support, and family well-being.

\section{References}

Amato, P. R., \& Keith, B. (1991). Parental divorce and the well-being of children: a metaanalysis. Psychological Bulletin, 110(1), 26-46. https://doi.org/10.1037/00332909.110.1.26

Ben-Arieh, A. (2008). The child indicators movement: Past, present and future. Child Indicators Research, 1(1), 3-16. https://doi.org/10.1007/s12187-007-9003-1

Hansen, T., Slagsvold, B., \& Moum, T. (2008). Financial satisfaction in old age: A satisfaction paradox or a result of accumulated wealth? Social Indicators happiness and UNDP's Analysis of Poverty, Wealth and Development. Journal of Happiness Studies, 10(1), 93-111. https://doi.org/10.1007/s11205-007-9234-z

Judicial Agency Religion. (2018). Laporan Tahunan Pengadilan Agama Cibinong. Kabupaten Bogor, Indonesia.

Khomsan, A. (2000). Teknik Pengukuran Pengetahuan Gizi. Bogor: Institut Pertanian Bogor

Laftman, S. B. (2009). Family structure and children's living conditions. a comparative study of 24 countries. Child Indicators Research, 3(1), 127-

147. https://doi.org/10.1007/s12187-009-9059-1

Main, G. (2019). Child poverty and subjective well-being: The impact of children's perceptions of fairness and involvement in intra-household sharing. Children and Youth Services Review, 30(4). https://doi.org/10.1016/j.childyouth.2017.06.031.

Main, G., Montserrat, C., Andresen, S., Bradshaw, J. \& Lee, B., J. (2017). Inequality, material well-being, and subjective well-being: Exploring associations for children across 15 diverse countries. Children and Youth Services Review, 97, 3-13. http://dx.doi.org/10.1016/j.childyouth.2017.06.033

Ministry of Women Empowerment and Child Protection. (2010). Laporan Akhir Kajian Awal Penyusunan Indikator Komposit Perlindungan Anak. Jakarta: Indonesia.

Monks, F. J., Knoers, A. M. P., \& Haditono, S. R. (2001). Psikologi Perkembangan: Pengantar dalam Berbagai Bagiannya. Yogyakarta: UGM Press.

Puspitawati, H. (2012). Gender dan Keluarga: Konsep dan Realita di Indonesia. Bogor: IPB Press.

Rees, G., \& Main, G. (2015). Children's view on their lives and well-being in 15 countries: An initial report on the Children's Worlds survey, 2013-2014. York, UK: Children's Worlds Project (ISCWeB).

Rini, Y. S. (2014). Komunikasi orang tua-anak dalam pengambilan keputusan pendidikan. Jurnal Interaksi, 3(2), 112-122. http://dx.doi.org/10.14710/interaksi.3.2.112-122

Schimmel, J. (2009). Development as happiness: the subjective perception of happiness and UNDP's analysis of poverty, wealth, and development. Journal of Happiness Studies, 10(1). http://dx.doi.org/10.1007/s10902-007-9063-4. 
Shek, D. T. L. (2007). Intact and non-intact families in Hong Kong. Journal of Divorce \& Remarriage, 47(1-2), 157-172. https://doi.org/10.1300/J087v47n01_09

Sirgy, M. J. (2018). The psychology of material well-being: applied research quality life. International Society for Quality of Life, 13(2), 273-301. http://dx.doi.org/10.1007/s11482-017-9590-z.

Sitepu, A. L. (2014). Keterlibatan anak remaja dalam pengambilan keputusan mengenai kebutuhannya serta kaitannya dengan pengasuhan orang tua. Retrieved from http://lib.ui.ac.id/naskahringkas/2016-08/S55349Ayusha\%20Laksmi\%20Sitepu\%20Pandebesi

Soemanto, R. B., \& Haryono, B. (2018). Kenakalan pelajar dalam keluarga single parent: studi kasus pada pelajar dalam keluarga single parent di Sekolah Menengah Atas Negeri 1 Girimarto, Wonogiri Tahun 2012/2013. Jurnal Analisa Sosiologi, 4(2).

Statistics Indonesia. (2017). Statistik Indonesia 2017. Jakarta: Badan Pusat Statistik.

Steele, F., Sigle-Rushton, W., \& Kravdal, Ø . (2009). Consequences of family disruption on children's educational outcomes in Norway. Demography, 46(3), 553-574. https://doi.org/10.1353/dem.0.0063

Yulianti, N., \& Silvy, M. (2013). Sikap pengelolaan keuangan dan perilaku perencanaan investasi keluarga di Surabaya. Journal of Business and Banking, 3(1), 57-68. http://dx.doi.org/10.14414/jbb.v3i1.254 